\title{
Fornøyelsessykdommer - fra moro til moral
}

\author{
De fleste former for lystbetont og ettertraktet atferd kan ende med avhengighet og elendighet. Det gjelder \\ røyking, sex, fotballtitting, kirkegang, mobiltelefonbruk, vitenskapelig artikkelskriving, videospill og gambling. \\ Men kanskje er ikke spillegalskap den galskapen som bør ha størst oppmerksomhet blant medisinere \\ og psykologer for øyeblikket.
}

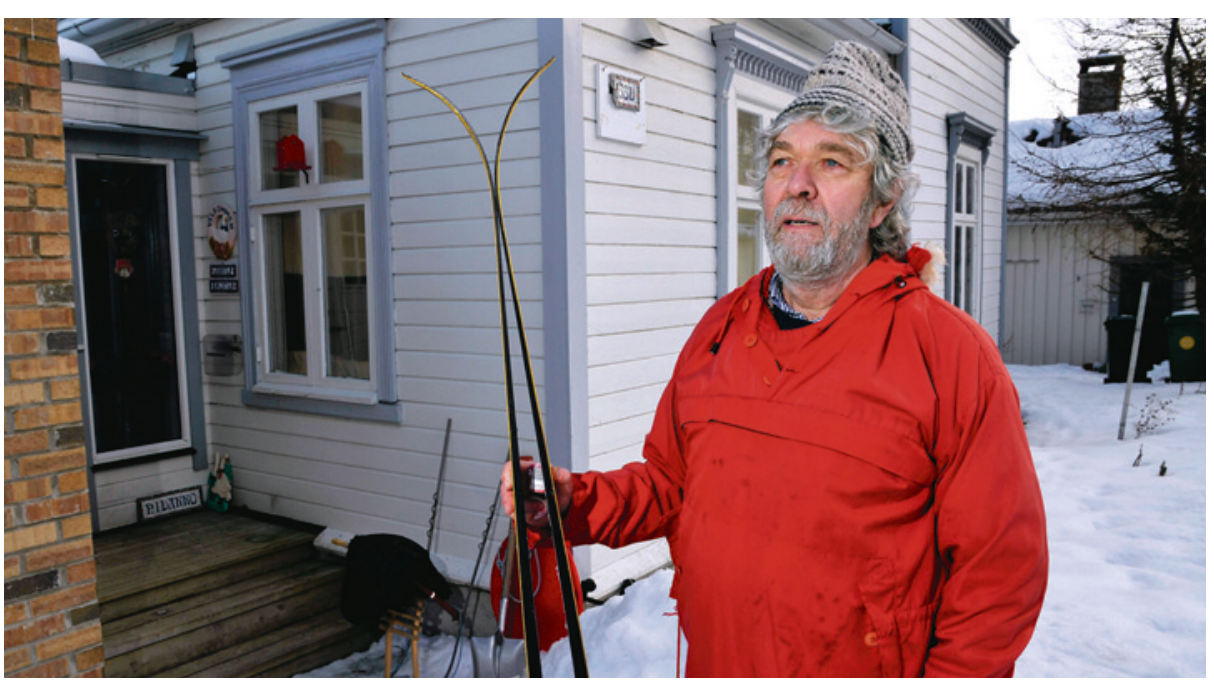

Kanskje er ikke spillegalskap den galskapen som bør ha størst oppmerksomhet blant medisinere og psykologer for øyeblikket, sier Arnulf Kolstad. Foto: Geir Otto Johansen/VG/Scanpix

\begin{abstract}
Arnulf Kolstad
arnulfk@hinesna.no

Arnulf Kolstad (f 1942) er sosialpsykolog, professor emeritus ved Psykologisk institutt, Norges teknisk-naturvitenskapelige universitet, og professor ved Høgskolen i Nesna.
\end{abstract}

PUBLISERT I BLOGGEN

(6) 20.12 .2013

\section{«Burde vi ikke applau- dere dem som klarer à avvike fra normene?»}

Er det så forferdelig om folk spiller på hest, enarmede gangstere, poker eller lever i en virtuell verden noen timer hver dag? Hvor skadelig er det egentlig sammenliknet med den bestialitet vi omgis av og som vi sjelden stiller spørsmål ved eller prøver å kurere? Kan (spille)lidenskap til og med ses på som positivt i en kultur som vår?

\section{Spillet}

Spill er jo en form for lek vi starter med tidlig. Betegnelsen på patologisk gambling er «ludomania», neppe fordi ludo er inngangsporten til patologisk gambling, men fordi «ludo» kommer av latinske «ludus» som oversettes med lek. En definisjon på ludomania, altså spilleavhengighet, er: «Lyst eller trang til å spille på tross av negative konsekvenser og ønske om å stoppe». Det er når gleden, leken og spenningen overdrives og blir en besettelse, at problemene kan oppstå. Den «gode følelsen» (også kalt «flyten») tar overhånd og det er vanskelig å komme ut av rusen. Leken knyttet til barnslig glede, kontakt og spenning kan paradoksalt bli et problem, en lidelse, for noen.

Spill har eksistert til alle tider. Det er funnet terninger og kortstokker i kulturer flere tusen år tilbake, for eksempel i Kina og i pyramidene i Egypt, men omfanget har neppe vært større enn nå. Dagligliv og arbeidsliv er blitt mer rutinepreget, mindre spennende. Lønnsslaveriet gir ingen emosjonell utfordring og folk etterlyser action og opplevelser. Underholdningsindustrien tilbyr sport og spill, og suget etter spenning vokser i befolkningen, godt hjulpet av spillpusherne i Norsk Tipping.

Sannsynligheten for å vinne er mindre enn å finne den berømte nåla i høystakken. Oddsen for toppgevinst i Viking Lotto er 1 til 250 millioner. Sannsynligheten for at du klarer å gjette de siste seks sifrene i mobilnummeret mitt på første forsøk er 1 til 1 million, eller 250 ganger mer sannsynlig.

En forutsetning for suksessen til Norsk Tipping er at folk ikke forstår eller tar hensyn til sannsynlighetsregning, men at de tenker som hovedpersonen i Dostovjevskijs roman Spilleren: «Det er riktig nok at av hundre spillere er det bare én som vinner. Men hva vedkommer det meg, hvis bare jeg vinner?»

\section{Lysten}

Lyst, lidenskap og begjær har dårlige vilkår $i$ en kultur som vår. Det kan avlæres og forsvinne og erstattes av en altoverskyggende fornuft, en rasjonalitet som kalkulerer lønnsomhet for enhver tanke, følelse og atferd. Ikke bare økonomisk lønnsomhet, men hva som lønner seg sosialt og karrieremessig, hva som «passer seg». Lysten undertrykkes av spørsmålet om hva vi bør gjøre, hva som er etisk og moralsk, hva samfunnet og «de andre» krever av oss.
Fremfor å fordømme dem som klarer å følge sine lyster og sitt begjær kunne vi heller spørre hvorfor så mange lever uten pasjon og spenning, følger spillereglene til punkt og prikke, gjør sin plikt og lever et tvers gjennom aktverdig liv. Hvordan skal vi forklare avståelsen av den spenningsopphissende lidenskapen som gir lyst og uforklarlig glede?

\section{Opprøret}

Skyldes det kravet om å være veloppdragen, konform og fornuftig først og fremst, uten lidenskaper, opprør eller galskap? Er mangelen på lidenskap og lystutlevelse typisk norsk, eller spesielt europeisk, noe vestlig, knyttet til en historisk samfunnsform eller produksjonsmåte, der avståelsen, kontrollen, regelstyringen er blitt idealet? Der lydigheten og karrieren $i$ andres øyne er blitt viktigere enn alt annet? Der det å produsere artikler som knapt noen leser, er blitt den altoverskyggende målsettingen for enhver akademiker?

Hos søramerikanske forfattere som Gabriel García Márquez og Jorge Mario Pedro Vargas Llosa oppdager vi at den formen for galskap vi mener bør kontrolleres og behandles, beskrives som noe positivt og nødvendig, ja, uutryddelig $\mathrm{i}$ andre kulturer, kulturer som riktignok mange $\mathrm{i}$ vår del av verden oppfatter som mer primitive. 
$\AA$ «hengi seg til lidenskapen eller nytelsen», bli opphisset og besatt, har dårlig klang i vår kultur. Det blir oppfattet som syndig, sykt og et tegn på at man ikke forstår sitt eget beste, ikke gjør det som sømmer seg $i$ andres øyne. Vi ser på overdreven nytelse som en sykdom og kaller slike folk «nytelsessyke».

\section{Gamblerens kvalitet}

Når noen begjærlig griper muligheten for å spille seg fra sans og samling, fra gård og grunn, skal vi kanskje se det som et symptom på at det tross alt er håp for en samfunnsform der avvik betraktes som en skam, en fare og et onde og der avståelse, konformitet og lydighet er høyeste moral. Burde vi ikke heller applaudere dem som klarer å avvike fra normene, fremfor å betrakte spillesuget som en individuell lidelse, en sykdom som må behandles?

Selvfølgelig skaper det problemer å følge lysten, lidenskapen og begjæret. Det kan skade en selv og andre, ikke minst ens nærmeste. Men hva er målestokken her? Er den planlagte, vel gjennomtenkte, «fornuftige», rasjonelle og lidenskapsløse tenkemåten, blottet for aggresjon og lyst, som gikk forut for krigene i Irak, Afghanistan og Libya for å ta noen aktuelle eksempler - mindre skadelig, mindre ødeleggende for andre, for sivile, uskyldige barn og gamle, enn de ufornuftige, ja irrasjonelle eskapader på travbanen, foran spilleautomatene eller ved pokerbordet i Las Vegas?

Er lystutfoldelsen til de spillesugne som har mistet kontrollen, enten det skyldes hest, enarmede banditter, aksjer på børsen eller i bingohallen, verre enn den langvarige, planlagte, godt kontrollerte, lidenskapsløse og «fornuftige» okkupasjonen av palestinsk territorium, støttet i praksis av alle demokratier i vest, til tross for lidelsene til millioner av palestinere i flyktningleirene?

Men dette kan da ikke sammenliknes med skadene av den ukontrollerte spillegalskapen - sier noen. Men hvem sier det, ja hvem bestemmer egentlig det? At dette ikke skal sammenliknes? Hvem skal definere hva vi skal snakke om? Hvem skal ha definisjonsmakten? Skal vi ikke for engangs skyld forsøke denne sammenlikningen mellom uretten og lidelsene forårsaket av normaliteten, fornuften og rasjonaliteten på den ene side, og skadene som følge av at lysten, lidenskapen og galskapen tar overhånd, på den andre? Skal vi ikke tillate oss i hvert fall å tenke over det? 